\title{
精神科病院における総合感冒薬による転倒事故の防止対策
}

\author{
加瀬浩二 ${ }^{* 1}$, 松田公子 ${ }^{1}$, 原 広一郎 ${ }^{2}$, 櫻井正太郎 ${ }^{3}$, 高山幸三 ${ }^{3}$, 浅井邦彦 $^{2}$ \\ 医療法人静和会浅井病院薬斉部 ${ }^{1}$, 医療法人静和会浅井病院精神科 ${ }^{2}$, 星薬科大学 $^{3}$
}

\section{Study on Prevention of Accidental Falls in Psychiatric Hospital Patients Using Cold Medicines}

\author{
Koji Kase ${ }^{* 1}$, Kimiko Matsuda ${ }^{1}$, Koichiro Hara², Shotaro Sakurai ${ }^{3}$, \\ Kozo Takayama and Kunihiko Asai ${ }^{2}$ \\ Department of Pharmacy, Asai Hospital ${ }^{1}$, Department of Psychiatry, Asai Hospital ${ }^{2}$, Hoshi University ${ }^{3}$ \\ $\left[\begin{array}{l}\text { Received February 6, } 2008 \\ \text { A ccepted September 30, 2008 }\end{array}\right]$
}

The frequency of accidental falls in psychiatric patients is reported to be markedly higher (46.5\%) than in patients in other medical departments $(15.7 \%)$. In order to prevent accidental falls, we provided physicians and nurses with pharma ceutical information on the adverse effects of cold medicines and traditional Chinese medicines. We also investigated the annual number of falls among inpatients before and after beginning our pharmaceutical information service. To do this, a questionnaire concerning cold medicines and traditional Chinese medicines was sent to physicians and nurses 2 years after starting the service. Owing to the provision of information, there were reductions in the annual number of falls (212 to 143), number of falls in patients taking cold medicines ( 8 to 1), percentage of falls in patients taking cold medicines among all falls (3.8\% to $0.7 \%)$, and frequency of prescribing cold medicines for the common cold ( $96 \%$ to $75 \%$ ). The questionnaire results also showed that $68 \%$ of physicians and nurses observed dizziness as an adverse effect of cold medicines, and $71 \%$ of physicians exercised caution with respect to the risk of falls due to cold medicines.

To analyze the causes of accidental falls, a self-organizing map (SOM) was applied to the clinical data. The results suggested that the administration of cold medicines together with comparatively low dosages of chlorpromazine, or an equiva lent antipsychotic, and two or more kinds of medication for Parkinson's disease was likely to lead to accidental falls. Thus, for patients having a high risk of falls, the co-administration of cold medicines and psychotropic drugs may further increase such risk.

Key words — cold medicine, Chinese medicine, accidental fall, information service, self-organizing map

\section{緒言}

精神科における転倒転落事故の発生頻度は $46.5 \%$ で,一般科の $15.7 \%$ と比較して高いと報告されてい る $^{121}$. この要因として, 増田らは一般科の転倒事故の要 因に加え，転倒の原因となりやすい薬阁の使用など精神 科特有の要因が重なることで転倒事故が発生していると 報告している゙ . 転倒事故の原因として，患者を取り巻 く環境，加齢による筋力の低下，視力障害，認知症やj つ病などの疾患, 乥れらに加え服用薬の影響などが挙げ られる ${ }^{3,4)}$. 特に抗精神病薬, 抗不安薬, 睡眠薬, 抗うつ 薬, 抗てんかん薬などを服用している患者では, 転倒の 危険性が高まるといわれている5, .

医療法人静和会浅井病院(以下，当院と略す)の 2004
年度ヒヤリ・ハット/事故報告書 521 件中 , 190 件(36.5 \%)が転倒・転落事故であった . 転倒事故は骨折などの 損傷から弚のまま寝たきりになる可能性が高く，入院患 者の約 9割が精神疾患患者や高齢者である当院にとっ て, 転倒回避に向けた取り組みは重要な課題である。

乥こで，当院では転倒事故防止を目的に，2004年 8 月に薬剂師・看護師・理学療法士を中心とした転倒転落 防止小委員会が発足した。2006年 3月から, 医師も委 員会に参加することとなり，ヒヤリ・ハット/事故報告 書を基に転倒事故の防止に向けての取り組みを行ってい る. 委員会において薬剤師は転倒事故を誘発する可能性 がある薬剂に関する情報提供や，転倒を繰り返す患者の 転倒事故回避に向けた処方変更の提案などを行っている． 委員会活動の中で,上気道炎に総合感冒薬 $\left(P L\right.$ 顆粒 ${ }^{\circledR}$; 塩野義製薬(株))が処方された患者が, 強いふらつきを呈 
し転倒したとの報告があった．弚こで，PL 顆粒 ${ }^{\circledR} と$ 転倒 との関係について注目し，薬斉師か転倒事故防止の観点 から，PL 顆粒 ${ }^{\circledR}$ 服用によって発生するふらつきなどの 副作用に関して，医師・看護師に情報提供を行い，漢方 薬(葛根湯)を代替薬とする処方提案を行った．

今回，情報提供前後のPL 顆粒 ${ }^{\circledR}$ と葛根湯の処方割合 の変化について調査・検討し，また，医療従事者に対し 情報提供後のPL 顆粒 ${ }^{\circledR}$ と葛根湯に関する意識調査を 行った .さらに，PL 顆粒 ${ }^{\circledR}$ の服用と転倒事故の関係につ いてデータ解析を実施し検討を行った．また，PL 顆粒 ${ }^{\circledR}$ 服用後に発生した転倒事故の症例もあわせて報告する .

$$
\text { 方法 }
$$

\section{1. 処方動向調査}

2005 年 5 月にPL 顆粒 ${ }^{\circledR}$ と葛根湯に関する情報提供を 行い，情報提供前(2004年 6 月〜2005年 5 月)と情報提 供後(2005年 6 月〜2006年 5 月)の 2 剂の処方件数を抽 出し, 処方割合の変化を調査した . また, 全転倒患者に おける総合感冒薬服用者の割合について調査した .さら に，全転倒患者数の比較も行った．

情報提供の内容としては, PL 顆粒 ${ }^{\circledR}$ が含有するメチレ ンジサリチル酸プロメタジンによると考えられる副作用 についての注意を喚起し，また，PL 顆粒 ${ }^{\circledR} の$ 代替薬とし て, 漢方薬専門医の助言を基に，薬阁師が作成した漢方 薬の処方例を示した。

\section{2. アンケート調査}

2007 年 6 月，情報提供後のPL 顆粒 ${ }^{\circledR}$ と葛根湯に関す る意識調査を，医師(40名)・看護スタッフ(223名)を対 象にアンケート形式で行った(表 $1 ， 2$ ).

3. 自己組織化マップ(Self-Organizing Map : SOM)によ る解析

情報提供前(2004年 6 月～2005年 5 月)に転倒した患 者(212例)を対象に，転倒事故を起こした患者と PL 顆 粒 ${ }^{\circledR}$ 服用との関係について, 対象薬剂を薬効分類し, 服 用薬剂数としてデータ化し，PL 顆粒 ${ }^{\circledR}$ 服用患者(8例)を 含めSOM による解析を行った．また，情報提供前後に PL 顆粒 ${ }^{\circledR}$ を服用していた患者(353例)と転倒事故との関 係についても解析を行った . 転倒患者が 353 例中 8 例と 少なかったため, ロジスティック重回帰分析の適用は不 可能であった .このため, SOM による解析を試みた . SOM は, 1982年, Kohonenにより提唱された多次元 データの 2 次元可視化技術であり，データ間の類似度に 応じて自己組織化マップを作成するものである．この手 法は, 大脳皮質の感覚野にみられる機能地図が，知覚経 験に基づく学習により形成されていく仕組みの本質的な 部分を取り出した興味深い脳神経回路の数理モデルであ る.また, 統計学的観点からは, 多次元データの線形写
表 1 . 医師に対するアンケート

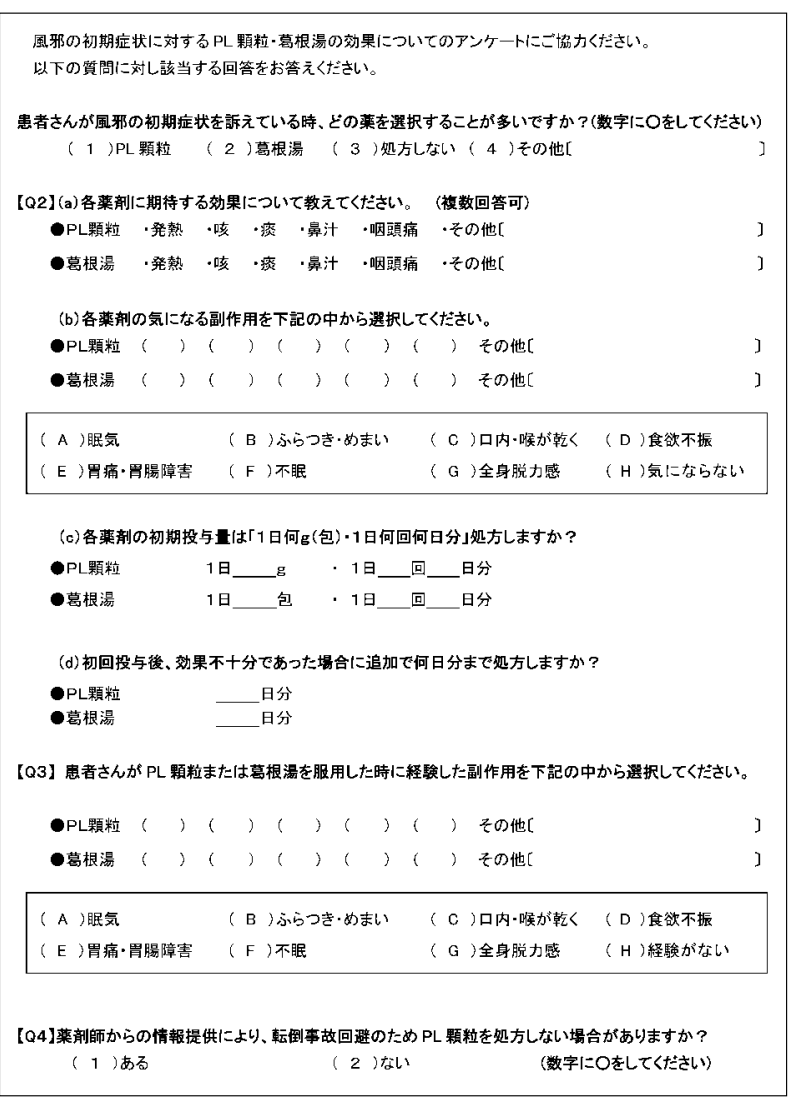

表 2 ．看護スタッフに対するアンケート

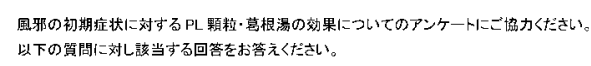

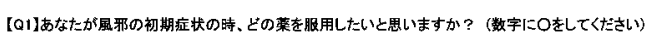

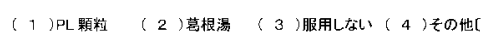

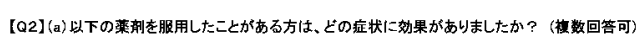

\begin{tabular}{|c|c|c|c|c|c|c|c|c|c|}
\hline •PL頪粒 & ·発㷫 & . 咳 & 一稳 & 乓; & 汁 & - 呕䫂痛 & ·その他 & & ] \\
\hline ・葛根晹 & ·発熱 & 咳 & -㻦 & 算 & 汁 & ·呕頙痛 & •その他 [ & & J \\
\hline \multicolumn{10}{|c|}{ 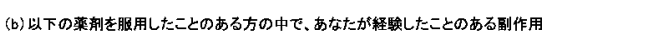 } \\
\hline \multicolumn{10}{|c|}{ を下記の中から選択してくオ゙きい。 } \\
\hline -PL顆柆 & $(3)$ & 6 & , & 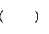 & 6 & $><$ & $\gamma \xi の$ 他[ & & 了 \\
\hline •葛根湯 & $(\quad)$ & 6 & , & ( ) & 6 & )$<$ & 了专の他 & & J \\
\hline 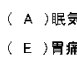 & ·胃晹焐 & & ( B & & & めむい & 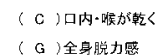 & 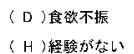 & \\
\hline
\end{tabular}

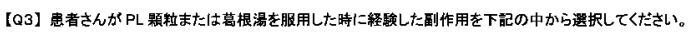

\begin{tabular}{|c|c|c|c|c|c|c|c|c|c|c|}
\hline ・苟根晹 & ( ) & 6 & , & 13 & 36 & ( ) & $<$ & 3 & その他 [ & \\
\hline ( & & & $(\mathrm{B})$ & 35.50 & pき- & めまい & & 60 & 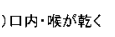 & （D）倉领不振 \\
\hline (E) 胃痛· & 胃晹障素 & & $(F)$ & 不眼 & & & & & )全身脱力感 & (H)絴暉がない \\
\hline
\end{tabular}

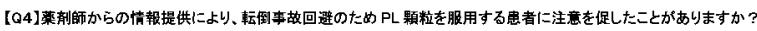
)るる (2) tal (数字にOをしてください)

像である主成分分析を非線形へと拡張したものと考える ことができ7，強力な分類手法としてさまざまな研究分 
野への応用が試みられている. 本研究では, SOM 解析 用のソフトウェアとして ,Viscovery ${ }^{\circledR}$ SOMine Version 4.0 (Eudaptics社)を使用した ·また，クラスター分割線には W ard 法を用いた .

\section{結＼cjkstart果}

\section{1. 転倒患者の背景}

情報提供前の転倒患者は，平均年齢 62.6 歳，男性 111 例(52\%)，女性 101 例(48\%)であった．また，情報提供 後では, 平均年齢 62.5 歳, 男性 74 例(52\%)，女性 69 例 (48\%)でありほぼ同じであった．また，情報提供前のPL 顆粒 ${ }^{\circledR}$ を服用した患者の平均年齡は 59.8 歳, 男性 6 例 (75 $\%)$ ，女性 2例(25\%)であった . 情報提供後の転倒患者は 1名であり，54歳，男性であった．

\section{2. 処方動向}

図 1 に示したようにPL 顆粒 ${ }^{\circledR}$ と葛根湯の処方件数の 割合は，情報提供前のPL 顆粒 ${ }^{\circledR} 96 \%$ (358/374例)に対 し，情報提供後は $75 \%$ (230/306 例)と減少していた(図 1).また，全転倒患者におけるPL 顆粒 ${ }^{\circledR}$ の服用者の割 合は，情報提供前 3.8\%(8/212 例)であったが，情報提供 後には $0.7 \%$ と(1/143例)減少していた．さらに，情報 提供前の転倒患者は 212 例であったが，情報提供後には 143 例と減少していた。

なお，同期間の葛根湯服用患者では，転倒事故の発生 はなかった .

\section{3. アンケート結果}

アンケートの回収率は, 医師 85\% (34/40 名), 看護ス タッフ 92\%(205/223名)であった .

図 2 に示したように，「患者が風邪の初期症状を訴え ているとき，どの薬剤を選択することが多いか」の項目 に対し，医師が選択することの多い薬剤はPL 顆粒が全 体の $79 \%$ を占めていた .

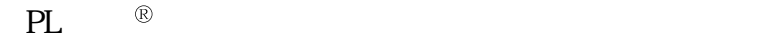

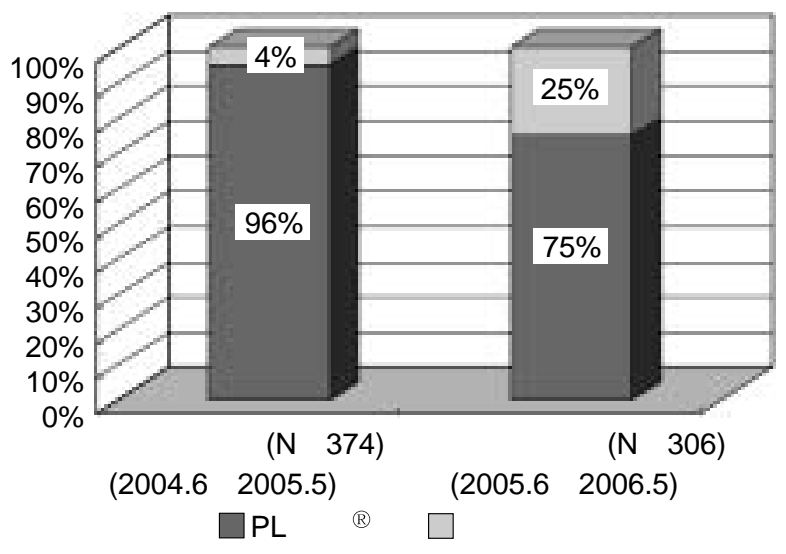

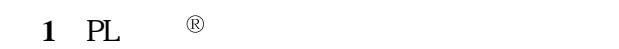

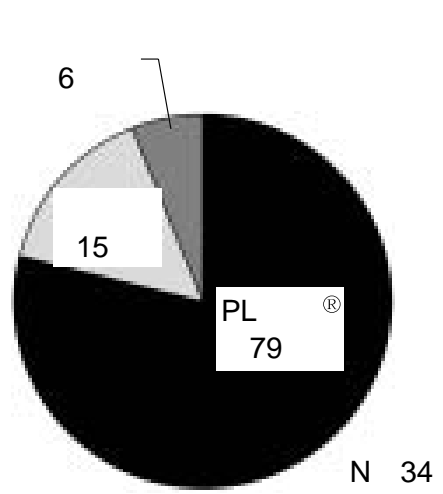

図 2 . 感冒時医師が処方する薬阂(表 1-Q 1)

対し，医師は発熱(29\%)・鼻汁(29\%)・咽頭痛(25\%)の症 状に対する効果を期待していた。

図 3 に示したように，「PL 顆粒间の気になる副作用」 についての項目に対し，医師が気している副作用の中で 眠気，ふらつき・めまいが全体の $73 \%$ を占めていた .

また，「看護スタッフ自身がPL 顆粒 ${ }^{\circledR}$ を服用したとき の副作用経験」の項目に対し，看護スタッフ自身が経験 した副作用の回答の中で，眠気，ふらつき・めまいが全 体の $53 \%$ を占めていた .

「医師が葛根湯を処方するときに気になる副作用」に おいて，気にならないという回答が全体の $55 \%$ を占め ていた。

「看護スタッフ自身が葛根湯を服用したときの副作用 経験」において，葛根湯を服用しても気になる副作用は 経験しなかったとの回答が全体の $72 \%$ を占めていた .

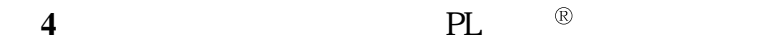
の服用時，患者に生じた副作用について」の項目に対 し，医療従事者の観察から患者がPL 顆粒 ${ }^{\circledR}$ 服用後に経 験したと考えられる副作用では，眠気，ふらつき・めま いが全体の $66 \%$ を占めていた .これに対して医療従事

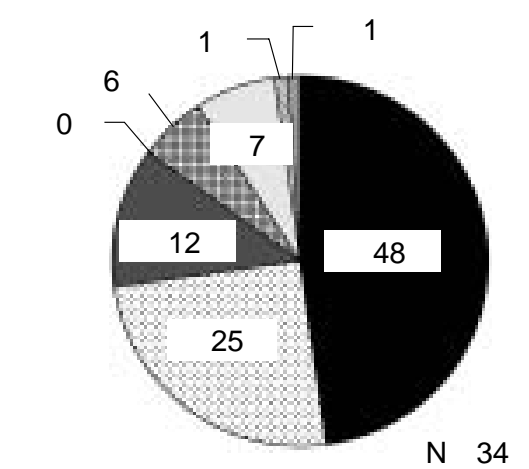
A : 眠気
B : ふらつき・めまい
C : 口内・喉が渴く
$D$ : 食欲不振
曲 $E$ ：胃痛・胃腸障害
$F ：$ 全身の脱力感
$\mathbb{N} G$ : 気にならない
その他

図 3 . 医師が注意しているPL 顆粒 ${ }^{\circledR} の$ 副作用(表 1-Q 2-b) 

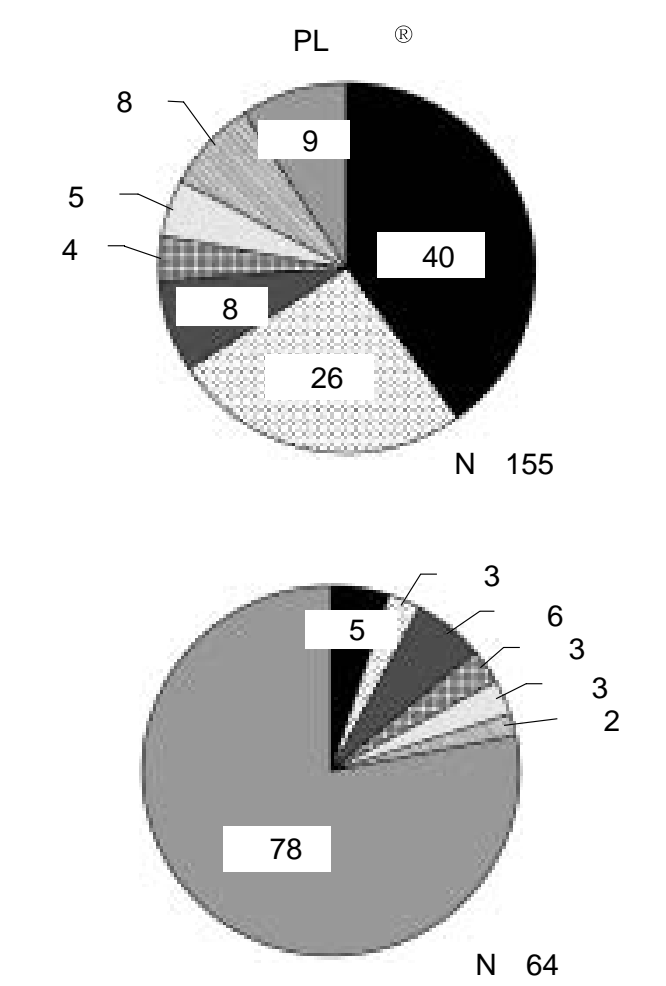
A : 眠気
B： ふらつき・めまい
C : 口内·喉が渇く
曲D：食欲不振
$E$ ：胃痛·胃腸障害 $\mathbb{N} F$ : 全身の脱力感
$G ：$ 気にならない

図 4.PL 顆粒 ${ }^{\circledR}$ または葛根湯によって患者に発症した 副作用状況(表 1 2-Q 3)

者の観察から患者が葛根湯服用後に経験したと考えられ る副作用は，気になる副作用はなかったとする回答が全 体の $78 \%$ を占めていた .

「薬剂師の情報提供により, 転倒事故回避のためPL 顆粒 ${ }^{\circledR}$ を処方しないことがあるか」の項目に対し，医師 の $71 \%$ が処方しない場合があると回答した .また「薬 剂師の情報提供により，患者がPL 顆粒量服用時に注意 を促すことがあるか」の項目に対し，看護スタッフの 71 \%がPL 顆粒®を服用する患者に対して特に気にかける ことはなかったと回答した .

\section{SOM による解析結果}

転倒患者の服用薬斉数のデータを解析した結果を図 $\mathbf{5}$ に示したが，転倒患者のうち，PL 顆粒 ${ }^{\circledR}$ を服用している 患者(図中左上の赤〜緑色のノード)は, クロルプロマジ ン(CP)換算値が比較的低い患者(水色〜青色のノード)で あるが , 複数の抗パーキンソン病薬(赤〜黄色のノード) とベンゾジアゼピン(BZ)系薬剂(橙〜黄色のノード)や抗 アレルギー薬(赤色のノード)を服用している可能性が示 唆された。

また，図 6 に示したように，情報提供前後 1 年間のPL 顆粒 ${ }^{\circledR}$ の服用患者 353 名を対象として解析した結果，転
倒患者 8名(図中右上の赤色のノード)のうち，3名は複 数の抗パーキンソン病薬(赤色のノード), BZ 系薬剂(黄 色のノード)，抗アレルギー薬(橙色のノード)や降圧・利 尿剂(橙色のノード)を服用しており，これに PL 顆粒㝵を 追加して服用した患者が転倒していた．また，5名の患 者は，他の併用薬斉の影響が少なく，PL 顆粒 ${ }^{\circledR} の$ 服用の みで転倒したと考えられた 。

これらの結果から，PL 顆粒®の服用は，転倒に対して 少なからず影響していることが示唆され，転倒の危険性 の高い患者では PL 顆粒 ${ }^{\circledR}$ を漢方薬に変更することが望 ましいと考えられた .

\section{考察}

意識調査から，医師はPL 顆粒 ${ }^{\circledR}$ の副作用である眠気， ふらつき・めまいなどに留意しながら処方しているとい う回答が，全体の $71 \%$ を占めており，薬剂師からの情 報提供を基に，転倒予防を意識して薬阂の選択を行って いると考えられる．結果として，情報提供前後の処方割 合において，PL 顆粒 ${ }^{\circledR} の$ 処方件数は減少傾向にあり，グ ラフには示していないが，2006年 6 月から 2007 年 5 月 の1年間での PL 顆粒®の処方割合は $70 \%(187 / 268$ 例 $)$ と さらに減少していた .

2004 年 8月より, 転倒転落防止小委員会では主にヒ ヤリ・ハット/事故報告書を基に転倒患者個々に対し， 再発予防のため看護師・理学療法士・薬剤師での症例検 討を行ってきた．2006年3月より，委員会に医師が参 加することになり，光の後入院患者に対してアセスメン 卜を行うなどの予防対策が徐々に行われるようになっ た . 情報提供前後において , 症例検討などの取り組みの 積み重ねにより医療従事者の転倒事故に対する意識が高 まり転倒事故の減少につながつたと考えられる．また， 今回の PL 顆粒最に関する情報提供は，医療従事者の意 識を高める結果となり，転倒患者数の減少に寄与できた と考える .

精神科特有の転倒事故発生要因に加え，平均服用期間

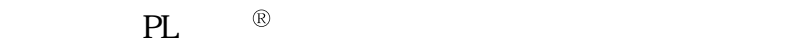
危険性がさらに増加すると考えられる．全転倒患者に対 するPL 顆粒 ${ }^{\circledR} の$ 服用者の割合は $3.8 \%$ から $0.7 \%$ と減少 傾向にあり, PL 顆粒 ${ }^{\mathrm{B}}$ から葛根湯への変更は, 転倒事故 の発生件数と転倒事故を起こす危険因子の軽減につなが ると考えられる.今回のPL 顆粒㹸に関する情報提供は， 転倒事故のリスクを増やさない取り組みの中の一つと考 えられる .

また，PL 顆粒 ${ }^{\circledR} の$ 副作用に関する意識の定着につい て，情報提供の 2 年後に行った医師・看護スタッフへの アンケート調査結果から検討した .

医師がPL 顆粒 ${ }^{\circledR}$ 処方する際，転倒事故の原因とな る眠気，ふららつきめまいなどの副作用に注意している との回答が全体の $70 \%$ 以上を占めているが , PL 顆粒 ${ }^{\circledR}$ 

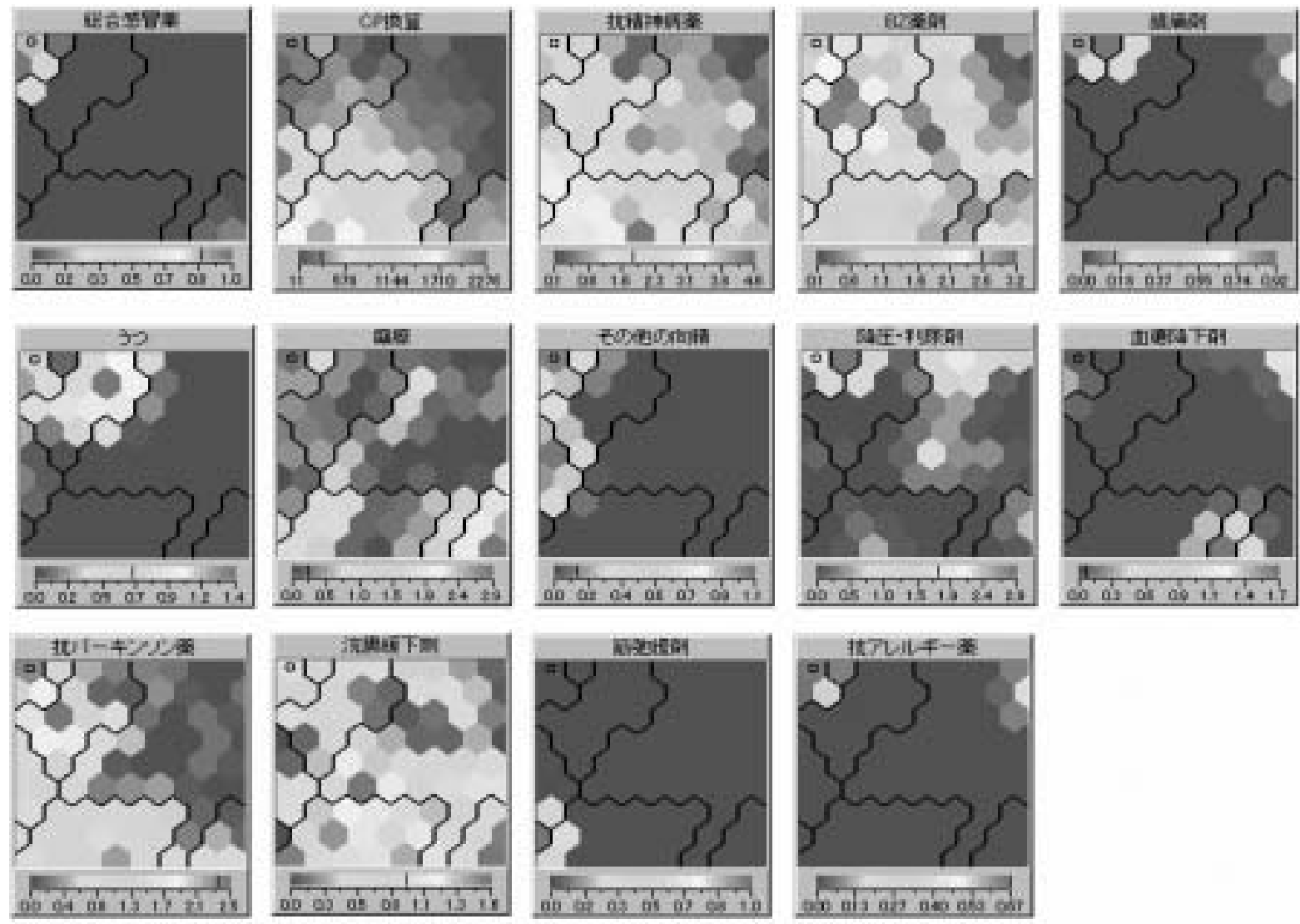

図 5 . 情報提供前 1 年間に転倒した患者(215名)を対象とした SOM による併用薬斉の検討 各クラスター分割線はW W ard 法により推定されたものである . また , 図中のノード (六角形)は類似の患者データが集約されたものであり, 赤色は最大の頻度を, 以後 , 橙色，黄色，緑色，水色，青色の順に頻度が低下することを示している．

を服用した患者に眠気，ふららつ・めまいなどの副作用 を経験していたとの回答が全体の $66 \%$ を占めていた . しかし, 現状では医師がPL 顆粒をを感冒症状の第一選 択薬として選択するとの回答が全体の $79 \%$ を占めてお り，実際に 2006 年 6 月から 2007 年 5 月では $70 \%$ の割 合でPL 顆粒芭が処方されていた .

このような現状から，PL 顆粒®の適正使用に向けた取 り組みは重要であり，個々の患者の転倒リスクを考慮し た上で , 副作用に関する注意や転倒の危険性の少ない代 替薬を提案するなどの情報提供を続けていくことが薬剤 師の役割として重要であると考えられる .

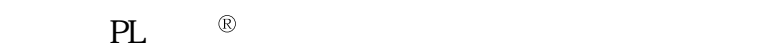
した .

$\mathrm{PL}$ 顆粒 ${ }^{\circledR} 1 \mathrm{~g}$ 中に含まれる成分は,サリチルアミド( 270 mg)，アセトアミノフェン(150 mg), 無水カフェイン(60 $\mathrm{mg})$, メチレンジサリチル酸プロメタジン(13.5 mg : 塩

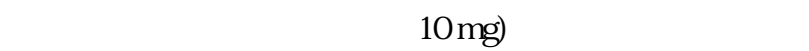
の用法・用量は 1日 3 4回，1回 1gである.PL 顆粒 ${ }^{\circledR}$ が転倒事故を引き起こす可能性として，1日用量中に塩 酸プロメタジンとして 30〜 $40 \mathrm{mg}$ 服用をすることにな り，これはパーキンソニズムでの治療用量に相当する． 塩酸プロメタジンは, フェノチアジン骨格を有する第一
世代ヒスタミン $\mathrm{H}_{1}$ 受容体拮抗薬に分類され, d遮断作 用を示し，抗アセチルコリン作用なども有する．また， 疎水性が高く血液脳関門を通過しやすいため，中枢神経 抑制作用を発現しやすく，鎮静，傾眠および倦怠感など が高率に現れるとされている8-10).

各医薬品の添付文書の調査研究から, 抗精神病薬, 抗 不安薬, 睡眠薬などのBZ 系薬剂, 抗うつ薬, 抗てんか ん薬などの薬斉に関して転倒・転落事故に影響を与える 記載事項が多かったとの報告がある ${ }^{11)}$. 今回のSOM に よる解析結果からは，PL 顆粒をを服用していない転倒患 者に対して，著しく影響を及ぼしていると考えられる薬 剂はみられなかった。また，製薬会社に対し PL 顆粒 ${ }^{\circledR}$ による転倒事故に関する情報の提供を求めたが，情報は ないとの返答であった . 服用している抗精神病薬の CP 換算値が比較的低い患者でも, 複数の抗パーキンソン病 薬，BZ 系薬剂，降圧・利尿剂や抗アレルギー薬などふ らつきなどの副作用か現れやすい薬斉の併用に加え，さ らにPL 顆粒『を服用することで転倒事故を起こす患者 がみられたことから，PL 顆粒®の服用か転倒事故のリス クを高める原因になることを考慮する必要があると考え られる。

今後, PL 顆粒 ${ }^{\circledR}$ 精神疾患患者や高龄者, 特に複数の 

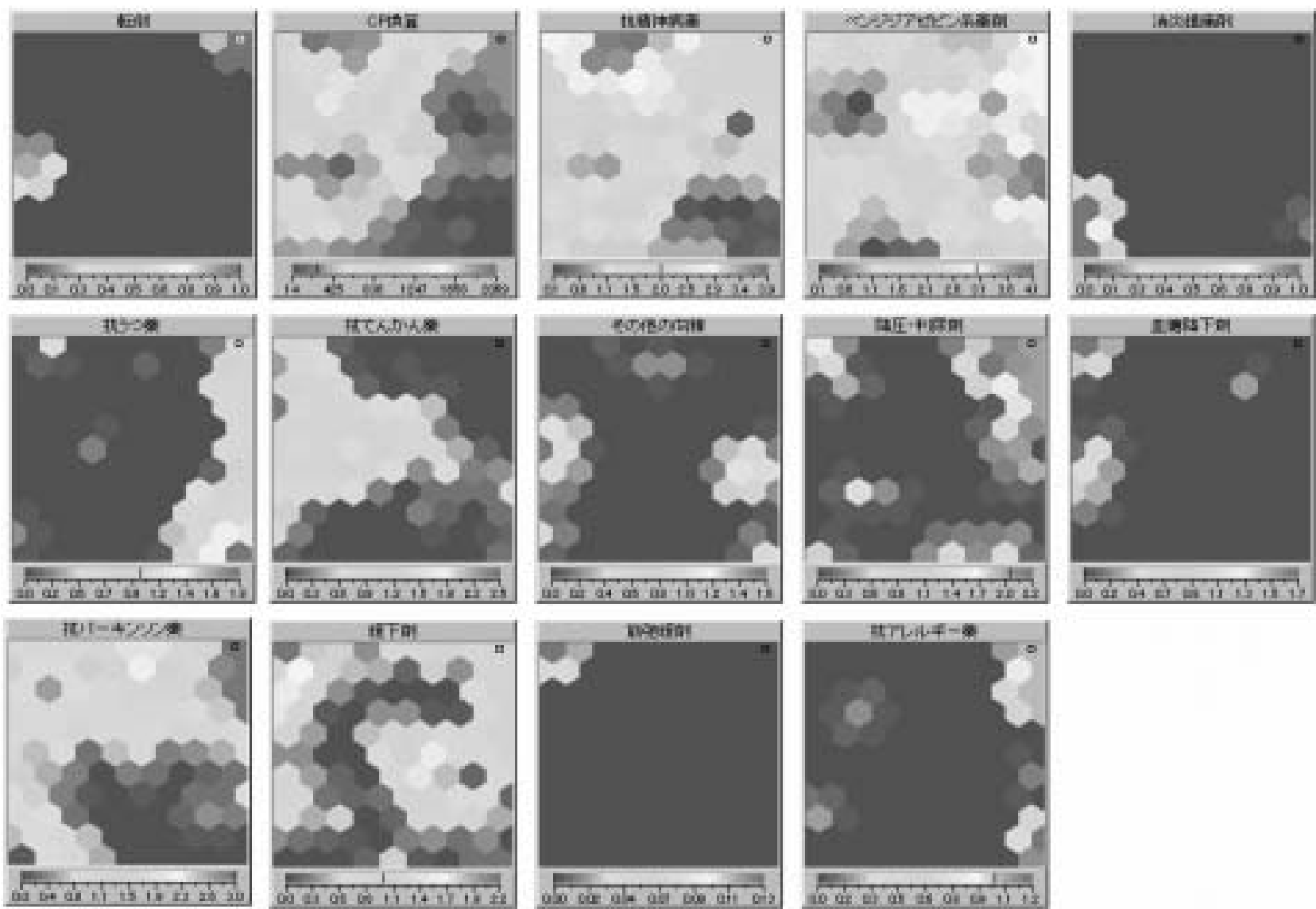

図 6 . 情報提供前 1 年間に PL 顆粒 ${ }^{\circledR}$ を服用した患者(365名)を対象とした SOM による併用薬斉の検討 図中のノード(六角形)は類似の患者データが集約されたものであり，赤色は最大の頻度を，以後， 橙色，黄色，緑色，水色，青色の順に頻度が低下することを示している．

パーキンソン病薬や BZ 系薬斉などを併用している患者 など，転倒リスクの高い患者に使用する場合，葛根湯な どリスクの少ない薬阂入積極的な切り替えを行う必要が あると考えられる.さらに転倒のリスクを高める薬剂が 処方される場合には，弚の薬斉の必要性と副作用発現の 危険性を考慮し，適正に使用することが必要と考える。

\section{引用文献}

1) 川村治子 “”ヒヤリ・ハット 11,000 事例によるエラー マップ完全本”, 医学書院，2003, pp. 1-6.

2) 社団法人日本精神科看護技術協会, 精神科看護白書 2002 $\rightarrow 2003$, 中央法規出版, 2002, pp.121-122.

3) 増田恵子 , 桂尚美 , 柏木嘉恵「精神科領域における転倒 転落の要因分析 - 総合病院における精神科入院患者 1年 間の調査から - , 日本看護学会論文集 - 成人看護 II - , 第 34 回，278-280 (2003).

4) 朝田隆 , 坂井輝男 “ “高齢者・認知症高齢者の転倒と光 の予防をめぐって”，老年精神医学杂倠誌，16，893-898 (2005).
5) 藤田茂, 鈴木荘太郎, 「転倒・転落と薬剤に関する研 究」, 病院管理, 41, 177-183 (2004).

6) 海老根いく子，飯野彰人，塚田和美 “”転倒・転落の発 生要因及び転倒・転落に影響する向精神薬の実態調査”, 日本看護学会論文集，看護管理，238-240 (2005).

7) 金澤洋祐, 川上準子, 星憲司, 川村鰠那, 岩谷香寿美, 佐藤渉, 浜田康次, 佐藤憲一, 抗菌薬副作用情報の自己 組織化マップ(SOM)を用いたビジュアル化と解析，医薬 品情報学 , 9 , 124-130 (2007).

8)上川雄一郎，“検証 抗ヒスタミン薬”, 永井博式, 黑沢 元博, スタンダード・マッキンタイヤ , 1998, pp.38-41.

9) 本橋茂, 転倒にかかわる薬, 看護学杂倠誌, 67, 770-775 (2003).

10) 谷内一彦, 加藤元久, 抗アレルギー薬, 抗精神病薬, 抗 うつ薬のヒスタミン $\mathrm{H}_{1}$ 拮抗作用と認知機能, 脳 21 , 10 , 85-90 (2007).

11) 小川幸雄, 椎崇, 安村貴子, 大谷義男, 黑山政一, 転 倒・転落事故に影響を与えると思われる副作用を有する 医薬品に関する研究, 医療薬学, 33, 1020-1026 (2007). 